\title{
Letter
}

\section{Public policies on sexually transmitted infections in Brazil}

\author{
Angélica Espinosa Miranda ${ }^{[1],[2],}$ Francisca Lidiane Sampaio Freitas ${ }^{[1],[3],}$ \\ Mauro Romero Leal de Passos ${ }^{[4]}$, Miguel Angel Aragón Lopez ${ }^{[5]}$ \\ and Gerson Fernando Mendes Pereira ${ }^{[1]}$
}

\author{
[1]. Ministério da Saúde, Secretaria de Vigilância em Saúde, Brasília, DF, Brasil. \\ [2]. Universidade Federal do Espírito Santo, Vitória, Brasil. \\ [3]. Universidade de Brasília, Programa de Pós-Graduação em Saúde Coletiva, Brasília, DF, Brasil. \\ [4]. Universidade Federal Fluminense, Departamento de Microbiologia e Parasitologia, Niterói, RJ, Brasil. \\ [5]. Organização Pan-Americana da Saúde, Unidade Técnica de Doenças Transmissíveis e Determinantes Ambientais da Saúde, Brasília, DF, Brasil.
}

\section{INTRODUCTION}

This article presents a brief history of public policies to address sexually transmitted infections (STI) in Brazil. It also discusses deficiencies and challenges to be considered by the country to formulate and implement future policies.

\section{GLOBAL OVERVIEW, REGION OF THE AMERICAS AND BRAZIL}

STI remains a global public health issue. In 2016, the World Health Organization (WHO) estimated a 376.4 million incidence of curable STI in people aged 15 to 49 . There were 127.2 million cases of chlamydia, 86.9 million cases of gonorrhea, and 6.3 million cases of syphilis. In the Region of the Americas, an estimated 29.8 million cases of chlamydia, 13.8 million cases of gonorrhea, and 2 million cases of syphilis were reported ${ }^{1}$.

These estimates indicate a high STI incidence and warrant the WHO global strategy and the establishment of priority measures to achieve STI elimination goals by 2030. This strategy focuses on (i) gonococcal antimicrobial resistance and chlamydial co-infection risk, (ii) congenital syphilis elimination, which requires increased testing and treatment of pregnant women and specific populations, and (iii) human papillomavirus (HPV) infection, with a focus on immunization to eliminate cervical cancer and anogenital warts ${ }^{2}$.

\footnotetext{
Corresponding author: Angélica Espinosa Miranda.

e-mail: angelica.miranda@aids.gov.br

(D) https://orcid.org/0000-0002-5556-8379

Received 01 February 2021

Accepted 10 March 2021
}

The Pan American Health Organization's (PAHO) Plan of Action for the Prevention and Control of HIV/STI (2016-2021) aims at expediting the elimination of the human immunodeficiency virus (HIV) and STI epidemics as public health issues in the Region of the Americas by $2030^{3}$. This plan incorporates regional strategies for the elimination of HIV and congenital syphilis vertical transmission, with specific criteria and indicators.

In Brazil, acquired syphilis, syphilis in pregnant women, and congenital syphilis cases are compulsorily notifiable ${ }^{4}$. Brazilian epidemiological data highlight the increase in syphilis cases for the period 2010-2018, when the congenital syphilis incidence rate increased almost four times, from 2.4 to 9.0 cases per thousand live births, and the syphilis detection rate in pregnant women increased about six times, from 3.5 to 21.4 cases per thousand live births. The acquired syphilis detection rate increased from 34.1 cases per 100,000 population in 2015 to 75.8 cases per 100,000 population in $2018^{5}$.

Brazilian nationwide-covering STI prevalence studies reveal the scale of the problem. Parturients attended in public maternity hospitals had a $9.8 \%$ prevalence of chlamydia and $1.0 \%$ of gonorrhea in $2011^{6}$, and men who sought care in STI clinics in $2005,13.1 \%$ of chlamydia and $18.4 \%$ of gonorrhea ${ }^{7}$. In 2015 , women living with HIV had a $2.1 \%$ prevalence of chlamydia and $0.9 \%$ of gonorrhea ${ }^{8}$, and $28.4 \%$ of high-risk HPV ${ }^{9}$. In 2017 , the prevalence of HPV infection was $25.4 \%$ in the cervix, $36.2 \%$ in the penile region, $25.7 \%$ in the anal area, and $11.9 \%$ in the oral region ${ }^{10}$. Another national study reported a $0.6 \%$ prevalence of syphilis in conscripts $^{11}$. In 2016, higher syphilis rates were observed in key population segments, such as men who have sex with men $(9.9 \%)^{12}$, female sex workers $(8.5 \%)^{13}$ and prisoners $(3.8 \%)^{14}$. 


\section{HISTORY OF THE RESPONSE TO IST IN BRAZIL}

Figure 1 outlines the historical milestones of major strategies and actions within the STI public policy scope in Brazil since creating the Brazilian National Program on Sexually Transmitted Diseases and AIDS (PN-DST/AIDS) in 1986.
The publishing of the first Clinical Protocol and Therapeutic Guidelines (PCDT) for Comprehensive Care for People with STI, approved by the National Committee for the Incorporation of Technologies in the Brazilian National Health System (Conitec), in 2015, is noteworthy ${ }^{15}$. The document establishes criteria for

\begin{tabular}{|c|c|}
\hline 2020 & $\begin{array}{l}\text { Updating of the Clinical Protocol and Therapeutic Guidelines (PCDT) for Comprehensive Care of People with Sexually Transmitted } \\
\text { Infections (STI) by the team of specialists in STI. } \\
\text { Webinars on the IST PCDT, in partnership with the Pan American Health Organization (PAHO) and the Brazilian Society for Sexually } \\
\text { Transmitted Diseases. } \\
\text { Institution of the Male Urethral Discharge Syndrome Surveillance by Ordinance GM/MS No. 1.553, June 17, 2020. } \\
\text { Launching of the complete genome sequencing results of } 548 \text { strains collected in the first issue of the gonococcus resistance } \\
\text { surveillance project (SenGono) (2015/2016). }\end{array}$ \\
\hline 2019 & $\begin{array}{l}\text { Establishment of the General Coordination for STI Surveillance in the Department of Chronic Conditions and STI's regulatory } \\
\text { framework, of the Health Surveillance Department (SVS), by Decree no. 9.795, of May 17, } 2019 . \\
\text { Conference with a group of specialists to discuss the IST PCDT that produced the document's present review. } \\
\text { Agreement with partners to renew the 'Strategic Actions Agenda for Syphilis Reduction in Brazil'. } \\
\text { Introduction of the Brazilian network of molecular tests for chlamydia and gonococcus in the states and Federal District. }\end{array}$ \\
\hline 2018 & $\begin{array}{l}\text { Updating of the 'How to prevent HIV and syphilis vertical transmission in your city' guide (partnership with the United Nations } \\
\text { Children's Fund [UNICEF]). } \\
\text { Partnership with the Federal Council of Medicine (CFM) for rapid testing in pregnant women, with the publication of CFM } \\
\text { Recommendation no. } 1 / 2018 \text {. } \\
\text { Extension of the human papillomavirus (HPV) vaccine for boys aged } 11 \text { to } 14 \text {, in the Brazilian National Health System (SUS). } \\
\text { Inclusion of chlamydial and gonococcal detection by molecular biology in the Table of Procedures, Drugs, Orthoses, Prostheses, and } \\
\text { Special Materials Management System. } \\
\text { Start of the new SenGono Project issue. } \\
\text { Start of phase II study on cefixime's clinical efficacy to treat active syphilis in non-pregnant women in Brazil. } \\
\text { Issuance of SCTIC/MS Ordinance No. } 42 \text {, October } 5,2018 \text {, on the IST PCDT second edition's approval. }\end{array}$ \\
\hline 2017 & $\begin{array}{l}\text { Establishment of the rapid response to syphilis project - 'Projeto Sífilis Não' ['No Syphilis Project'] } \\
\text { Publishing of the 'PCDT for the Prevention of HIV, Syphilis and Viral Hepatitis Vertical Transmission' } 2^{\text {nd }} \text { edition. } \\
\text { Purchase and distribution of crystalline penicillin in centralized mode by the Ministry of Health. } \\
\text { Inclusion of STI drugs in the National Essential Medicines List. } \\
\text { Updating of non-complicated gonococcal anogenital infection (urethra, cervix, and rectum) treatment. } \\
\text { Release of previously unpublished Brazilian data on gonococcal susceptibility to antimicrobials in the SenGono Project scope. } \\
\text { Establishment of the third October Saturday as the 'National Day for Combating Syphilis and Congenital Syphilis', a Bill approved by } \\
\text { the House of Representatives, made official by Act no. } 13.430 \text { of March } 31,2017 \text {, sanctioned by the President of the Republic. } \\
\text { Initiation of SUS incorporation of HPV vaccine for boys aged } 12 \text { and } 13 \text {. } \\
\text { Extension in SUS of the HPV vaccine for boys and men living with HIV aged } 9 \text { to } 26 \text {, people have undergone solid organ and bone } \\
\text { marrow transplants and cancer patients. } \\
\text { Presentation of the Epidemiological Study on the National Prevalence of HPV Infection (POP-Brazil Study) preliminary results. }\end{array}$ \\
\hline 2016 & $\begin{array}{l}\text { Release of the 'Strategic Actions Agenda for Syphilis Reduction in Brazil'. } \\
\text { Publishing of the 'Technical Manual for Syphilis Diagnosis', approved by Ordinance GM/MS no. 2.012, October 19, } 2016 . \\
\text { Replacement/update of the term sexually transmitted disease (STD) by STI, under the definition of the then Department of } \\
\text { Surveillance, Prevention and Control of STI, HIVIAIDS and Viral Hepatitis. } \\
\text { Updating of the STI Serial Album for health professionals. } \\
\text { Partnership with the Federal Nursing Council (Cofen) for rapid HIV, syphilis, and viral hepatitis testing, with the publication of Cofen } \\
\text { Decision no. } 244 / 2016 . \\
\text { Release of the syphilis indicators and basic data panel (syphilis in pregnant women and congenital syphilis). } \\
\text { Purchase and distribution of benzathine penicillin in centralized mode by the Ministry of Health. } \\
\text { Inclusion of male urethral discharge syndrome in the national list of diseases and illnesses to be monitored through the surveillance } \\
\text { strategy in sentinel units. } \\
\text { Start of the POP-Brazil Study. }\end{array}$ \\
\hline
\end{tabular}

FIGURE 1: Historical milestones of the response to sexually transmitted infections in Brazil, $1986-2020$. 
FIGURE 1: Continuation.

\begin{tabular}{|c|c|}
\hline 2015 & $\begin{array}{l}\text { Publishing of the first PCDT for Comprehensive Care for People with STI. } \\
\text { Publishing of the first PCDT for Prevention of HIV, Syphilis and Viral Hepatitis Vertical Transmission. } \\
\text { Publishing of the 'Good Practices Booklet on Penicillin Use in Primary Health Care. } \\
\text { Partnership with Cofen to expand penicillin provision in primary health care, by the nursing staff, with the publication of Cofen Decision } \\
\text { no. 0094/2015. } \\
\text { New edition and expansion of the SenGono Project. } \\
\text { Extension of the HPV vaccine in SUS for girls and women aged } 9 \text { to } 26 \text { living with HIV. } \\
\text { Decentralization of rapid syphilis tests for primary health care units and maternity hospitals. }\end{array}$ \\
\hline 2014 & $\begin{array}{l}\text { Publishing of the 'Vertical Transmission Research Protocol'. } \\
\text { Updating of the syphilis diagnostic course in the permanent education program in STI diagnosis (Telelab). } \\
\text { Inclusion of the HPV vaccine in the SUS for girls aged } 9 \text { to } 13 . \\
\text { Realization of the Brazilian National STI Public Consultation Forum }\end{array}$ \\
\hline 2012 & Implementation of syphilis and HIV rapid testing in the prenatal routine. \\
\hline 2011 & Establishment of Rede Cegonha [Stork Network]. \\
\hline 2010 & Acquired syphilis became of compulsory notification. \\
\hline 2009 & $\begin{array}{l}\text { Brazilian National STD/AIDS Programme becomes Department of Sexually Transmitted Diseases, AIDS and Viral Hepatitis, under the } \\
\text { SVS/Ministry of Health } \\
\text { Incorporação de teste diagnósticos de clamídia e gonorreia na tabela de procedimentos do SUS }\end{array}$ \\
\hline 2008 & $\begin{array}{l}\text { Publishing of the 'How to prevent HIV and syphilis vertical transmission in your city' guide, in partnership with UNICEF. } \\
\text { Publishing of the 'STD prevalences and relative frequencies in selected populations of six Brazilian capitals, 2005' research. }\end{array}$ \\
\hline 2007 & $\begin{array}{l}\text { Publishing of the 'Operational Plan for HIV and Syphilis Vertical Transmission Reduction'. } \\
\text { Publishing of the 'HIV and Syphilis Vertical Transmission Prevention Protocol'. } \\
\text { SenGono Project first implementation initiatives. }\end{array}$ \\
\hline 2006 & $\begin{array}{l}\text { Publishing the 'STI Control Manual' (4 }{ }^{\text {th }} \text { edition) and the 'Congenital Syphilis Control Pocket Manual'. } \\
\text { Publishing of the 'STD Serial Album'. } \\
\text { Publicação do 'Caderno de Atenção Básica 18: HIV/Aids, Hepatites e outras DST'. }\end{array}$ \\
\hline 2005 & $\begin{array}{l}\text { Syphilis in pregnant women became of compulsory notification. } \\
\text { Creation of the Gonococcal Resistance Brazilian National Surveillance Network. }\end{array}$ \\
\hline 2004 & Inclusion of the venereal disease research laboratory (VDRL) data in the SUS Hospital Information System (SIH/SUS). \\
\hline 2003 & Updating of the congenital syphilis case definition. \\
\hline 1999 & Publishing of the 'STD Control Manual' $3^{\text {rd }}$ edition \\
\hline 1998 & The first national initiative by the Brazilian Ministry of Health to determine gonococcal susceptibility to antimicrobials ${ }^{38}$. \\
\hline 1997 & $\begin{array}{l}\text { Publishing of the 'STD Control Manual' 2nd edition. } \\
\text { Implantation of the Telelab system. }\end{array}$ \\
\hline 1996 & PAHO/WHO invitation to establish a gonococcus resistance surveillance laboratory network. \\
\hline 1993 & $\begin{array}{l}\text { Publishing of the 'STD Control Manual' } 1^{\text {st }} \text { edition. } \\
\text { Publishing of the 'Congenital Syphilis Elimination Technical Bases'. }\end{array}$ \\
\hline 1986 & $\begin{array}{l}\text { Creation of the then Brazilian National Program on STD and AIDS (NP-DST/AIDS). } \\
\text { Congenital syphilis became of compulsory notification. }\end{array}$ \\
\hline
\end{tabular}

diagnosis, advocates treatment, sets clinical control mechanisms - to be followed by the Brazilian National Health System (SUS) managers - is grounded in scientific evidence, and assesses efficacy, safety, effectiveness, and cost-effectiveness parameters of the recommended technologies ${ }^{16}$. In that publication, the term sexually transmitted disease was replaced by STI, thereby matching the WHO designation ${ }^{3}$ and raising Brazil's awareness of asymptomatic infections and not just illness with signs and symptoms. The PCDT was re-examined and approved by Conitec in $2018^{17}$.

In the period 2015-2016, the Ministry of Health's partnership with the Federal University of Santa Catarina and sentinel sites for the elaboration of a gonococcal resistance study (SenGono Project) made possible the first Brazilian gonococcal antimicrobial susceptibility surveillance program. The nationwide surveillance research analyzed gonococcal strains at seven sentinel sites (composed of STI services and local support laboratories) and found high tetracycline, penicillin, and ciprofloxacin resistance in the bacteria ${ }^{18}$.

In 2018, a new phase of the SenGono Project started with installing more collection sites and the inclusion of two new antimicrobials (spectinomycin and gentamicin) in the analyses. Within the SenGono Project, the following are undergoing research: 
Neisseria gonorrhoeae, Chlamydia trachomatis, Mycoplasma genitalium, and Trichomonas vaginalis, in urethral discharge samples; and herpes simplex virus types 1 and 2, Treponema pallidum and Haemophilus ducreyi, in genital ulcer samples ${ }^{19}$.

The SenGono Project results led to the publication, on June 17, 2020, of Ordinance GM/MS no. 1.553/2020, by which the Ministry of Health instituted the sentinel surveillance of male urethral discharge syndrome to monitor data in qualified health units ${ }^{20}$.

Considering the global and national penicillin supply shortage and the difficulties for its acquisition by states and municipalities in the period 2014-2016, the publication of the 'Strategic Actions Agenda for Syphilis Reduction in Brazil' in 2016 ${ }^{21}$, as a response to the epidemic declared by the Ministry of Health, played a critical role in the decision for the centralized acquisition of these drugs, reserved to the same Ministry of Health. Benzathine and crystalline penicillin for syphilis treatment became part of the pharmaceutical assistance strategic component in Brazil. Doxycycline was also expanded for the treatment of syphilis, donovanosis, and pelvic inflammatory disease ${ }^{22}$. The penicillin mentioned above global shortage led to the search for effective alternatives for syphilis treatment. For example, in 2018, phase II of a clinical trial was initiated to evaluate the efficacy of cefixime in the treatment of active syphilis in non-pregnant women, establish safe alternative therapeutic options, and support efforts to end congenital syphilis ${ }^{23}$.

Following the HPV vaccination inclusion in SUS, the need for monitoring the impact of such immunization on the specific population was perceived. Research on HPV prevalence in Brazil was scarce until then ${ }^{10}$. In 2016, an HPV infection prevalence national study was started (POP-Brazil Study), a Ministry of Health partnership, amongst other institutions, with the Moinhos de Vento Hospital Association of Porto Alegre, RS, Brazil. The research sought to determine the HPV prevalence in sexually active people, aged 16 to 25, in all Brazilian capitals, and to investigate regional differences in prevalence and viral types; its final results will fill the epidemiological information gap, and contribute to establish a baseline and assess the HPV vaccination impact. The research's preliminary results presented publicly already in 2016, estimated a high HPV prevalence (54.6\%), of which $38.4 \%$ were high-risk HPV for cancer risk ${ }^{24}$.

\section{CHALLENGES AND DEFICIENCIES FOR STI CONTROL}

The fast antimicrobial resistance growth of Neisseria gonorrhoeae to several antibiotics threatens the efforts for controlling this infection. $66 \%$ of the 67 countries participating in the Gonococcal Antimicrobial Surveillance Programme have already shown increased clinical and in vitro resistance to broad-spectrum cephalosporins in 2009-2014, and it is the only remaining first-line monotherapy for gonorrhea contro $^{25}$. Research developments must have priority, including the development of new antimicrobials for treatment, of a gonococcal vaccine, and new rapid tests, with simultaneous detection of both the gonococcus and antimicrobial resistance, for diagnosis and surveillance ${ }^{26}$.

Some challenging goals in syphilis control include eliminating vertical transmission, improving case surveillance, developing more accurate tests to diagnose active syphilis, neurosyphilis, and congenital syphilis, increasing access for the most vulnerable populations, and developing alternative oral drugs and vaccines against Treponema pallidum ${ }^{27}$.

Lack of knowledge and fake news on immunization are examples of contributing factors to low vaccination coverage for HPV. Health care integration with schools and communities is central to achieve better indicators since well-informed adolescents are potential communicators of such information to their parents ${ }^{28,29}$. It is also relevant to promote health information, education, and communication aimed at professionals in the field to expand vaccination coverage ${ }^{28,30}$.

\section{FINAL CONSIDERATIONS}

Challenges and deficiencies persist in the formulation and implementation of public policies in IST in Brazil. In such a scenario, there is a permanent need for (i) strengthening the role of primary health care in comprehensive care to people with STI and their sex partners, (ii) ensuring adequate vaccination coverage against HPV and viral hepatitis A and B, (iii) promoting health information, education, and communication, (iv) expand access to STI testing and treatment, with emphasis on the most vulnerable populations, (v) notify sex partners, and (vi) qualify health professionals' approach to sexual health matters, in addition to screening for asymptomatic, prevention, clinical-laboratory management, and surveillance of sexually transmitted infection cases.

\section{ORCID}

Angélica Espinosa Miranda - 0000-0002-5556-8379

Francisca Lidiane Sampaio Freitas - 0000-0003-1344-6389

Mauro Romero Leal de Passos - 0000-0002-6183-7985

Miguel Angel Aragón Lopez - 0000-0001-8400-2043

Gerson Fernando Mendes Pereira - 0000-0001-8886-1662

\section{REFERENCES}

1. Rowley J, Vander Hoorn S, Korenromp E, Low N, Unemo M, AbuRaddad LJ, et al. Chlamydia, gonorrhoea, trichomoniasis and syphilis: global prevalence and incidence estimates, 2016. Bull World Heal Organ [Internet]. 2019 Aug [cited 2020 Sep 10];97(8):548-62. Available from: https://dx.doi.org/10.2471\%2FBLT.18.228486

2. World Health Organization - WHO. Global health sector strategy on sexually transmitted infections 2016-2021 [Internet]. Genebra: World Health Organization; 2016 [cited 2020 Sep 10]. 64 p. Available from: http://www.who.int/reproductivehealth/publications/rtis/ghss-stis/en/

3. Organização Pan-Americana de Saúde - OPAS. Organização Mundial da Saúde - OMS. Plano de ação para a prevenção e o controle do HIV e de infecções sexualmente transmissíveis [Internet]. Washington, D.C.: OPAS, OMS; 2016 [cited 2020 jun 14]. 401 p. Available from: http://iris.paho.org/xmlui/bitstream/handle/123456789/34077/ CD552017-por.pdf?sequence $=1 \&$ is Allowed $=y$

4. Brasil. Ministério da Saúde. Portaria de Consolidação MS/GM n. 4, de 28 de setembro de 2017. Consolidação das normas sobre os sistemas e os subsistemas do Sistema Único de Saúde [Internet]. Diário Oficial da União, Brasília (DF), 2017 oct 3 [cited 2020 sep 10];Suplemento:288. Available from: http://bvsms.saude.gov.br/bvs/saudelegis/gm/2017/ prc0004 $03 \quad 10 \quad 2017 . \mathrm{html}$ 
5. Ministério da Saúde (BR). Secretaria de Vigilância em Saúde. Departamento de Doenças de Condições Crônicas e Infecções Sexualmente Transmissíveis. Sífilis 2019. Bol Epidemiol [Internet]. 2019 oct [cited 2020 sep 10]; especial. Available from: http://www.aids. gov.br/pt-br/pub/2019/boletim-epidemiologico-sifilis-2019

6. Pinto VM, Szwarcwald CL, Baroni C, Stringari LL, Inocêncio LA, Miranda AE. Chlamydia trachomatis prevalence and risk behaviors in parturient women aged 15 to 24 in Brazil. Sex Transm Dis [Internet]. 2011 Oct [cited 2020 Sep 10];38(10):957-61. Available from: https://doi. org/10.1097/olq.0b013e31822037fc

7. Barbosa MJ, Moherdaui F, Pinto VM, Ribeiro D, Cleuton M, Miranda AE. Prevalence of Neisseria gonorrhoeae and chlamydia trachomatis infection in men attending STD clinics in Brazil. Rev Soc Bras Med Trop [Internet]. 2010 Sep-Oct [cited 2020 Sep 10];43(5):500-3. Available from: http://dx.doi.org/10.1590/S0037-86822010000500005

8. Miranda AE, Silveira MF, Travassos AG, Tenório T, Val ICC, Lannoy L, et al. Prevalence of chlamydia trachomatis and Neisseria gonorrhea and associated factors among women living with Human Immunodeficiency Virus in Brazil: a multicenter study. Braz J Infect Dis [Internet]. 2017 Jul-Aug [cited 2020 Sep 10];21(4):402-7. Available from: http://dx.doi. org/10.1016/j.bjid.2017.03.014

9. Miranda AE, Silveira MF, Travassos AG, Tenório T, Val ICC, Lannoy L, et al. High-risk papillomavirus infection among women living with human immunodeficiency virus: Brazilian multicentric study. J Med Virol [Internet]. 2017 Dec [cited 2020 Sep 10];89(12):2217-23. Available from: https://doi.org/10.1002/jmv.24906

10. Colpani V, Falcetta FS, Bidinotto AB, Kops NL, Falavigna M, Hammes LS, et al. Prevalence of human papillomavirus (HPV) in Brazil: A systematic review and meta-analysis. PLoS One [Internet]. $2020 \mathrm{Feb}$ [cited 2020 Sep 10];15(2):e00229154. Available from: https://doi. org/10.1371/journal.pone.0229154

11. Motta LR, Sperhacke RD, Adami AG, Kato SK, Vanni AC, Paganella MP, et al. Syphilis prevalence and risk factors among young men presenting to the Brazilian Army in 2016: results from a national survey. Medicine (Baltimore) [Internet]. 2018 Nov [cited 2020 Sep 10];97(47):e13309. Available from: https://doi.org/10.1097/md.0000000000013309

12. Cunha CB, Friedman RK, Boni RB, Gaydos C, Guimarães MR, Siqueira BH, et al. Chlamydia trachomatis, Neisseria gonorrhoeae and syphilis among men who have sex with men in Brazil. BMC Public Health [Internet]. 2015 Jul [cited 2020 Sep 10];15:686. Available from: https://doi.org/10.1186/s12889-015-2002-0

13. Ferreira-Júnior ODC, Guimarães MDC, Damacena GN, Almeida WS, Souza-Júnior PRB, Szwarcwald CL, et al. Prevalence estimates of HIV, syphilis, hepatitis B and C among female sex workers (FSW) in Brazil, 2016. Medicine (Baltimore) [Internet]. 2018 May [cited 2020 Sep 10];97(1S Suppl 1):S3-8. Available from: https://doi.org/10.1097/ md.0000000000009218

14. Correa ME, Croda J, Castro ARCM, Oliveira SMVL, Pompilio MA, Souza RO, et al. High prevalence of treponema pallidum infection in Brazilian prisoners. Am J Trop Med Hyg [Internet]. 2017 Oct [cited 2020 Sep 10];97(4):1078-84. Available from: https://dx.doi. org/10.4269\%2Fajtmh.17-0098

15. Brasil. Ministério da Saúde. Secretaria de Ciência, Tecnologia, Inovação e Insumos Estratégicos em Saúde. Portaria MS/SCTIE ${ }^{\circ}$ 53, de $1^{\circ}$ de outubro de 2015. Torna pública a decisão de aprovar o Protocolo Clínico e Diretrizes Terapêuticas (PCDT) de infecções sexualmente transmissíveis no âmbito do Sistema Único de Saúde - SUS [Internet]. Diário Oficial da União, Brasília (DF), 2015 oct 5 [cited 2020 sep 10];Seção I:691. Available from: http://bvsms.saude.gov.br/bvs/ saudelegis/sctie/2015/prt0053 $01 \quad 10 \_2015 . h$ html
16. Brasil. Presidência da República. Casa Civil. Lei $\mathrm{n}^{\circ}$ 12.401, de 28 de abril de 2011. Altera a Lei $\mathrm{n}^{\circ} 8.080$, de 19 de setembro de 1990, para dispor sobre a assistência terapêutica e a incorporação de tecnologia em saúde no âmbito do Sistema Único de Saúde - SUS [Internet]. Diário Oficial da União, Brasília (DF), 2011 apr 29 [cited 2020 sep 10]:Seção I. Available from: http://www.planalto.gov.br/ccivil 03/ Ato20112014/2011/Lei/L12401.htm

17. Brasil. Ministério da Saúde. Portaria MS/SCTIE $n^{\circ} 42$, de 5 de outubro de. Torna pública a decisão de aprovar o Protocolo Clínico e Diretrizes Terapêuticas para Atenção Integral às Pessoas com Infecções Sexualmente Transmissíveis (IST), no âmbito do Sistema Único de Saúde - SUS [Internet]. Diário Oficial da União, Brasília (DF), 2018 oct 8 [cited 2020 sep 10];Seção I:88. Available from: http://bvsms.saude. gov.br/bvs/saudelegis/sctie/2018/prt0042 $08 \quad 10 \quad 2018 . h$ tml

18. Bazzo ML, Golfetto L, Gaspar PC, Pires AF, Ramos MC, Franchini $\mathrm{M}$, et al. First nationwide antimicrobial susceptibility surveillance for Neisseria gonorrhoeae in Brazil, 2015-16. J Antimicrob Chemother [Internet]. 2018 Jul [cited 2020 Sep 10];73(7):1854-61. Available from: https://doi.org/10.1093/jac/dky090

19. Ministério da Saúde (BR). Secretaria de Vigilância em Saúde. Vigilância da resistência do gonococo aos antimicrobianos. Bol Epidemiol [Internet]. 2020 jul [cited 2020 sep 10];51(2). Available from: https://www.saude.gov.br/images/pdf/2020/July/09/Boletimepidemiologico-SVS-27-06.07.2020.pdf

20. Brasil. Ministério da Saúde. Portaria MS/GM no 1.553, de 17 de junho de 2020. Altera a portaria de consolidação $n^{\circ} 5 / \mathrm{GM} / \mathrm{MS}$, de 28 de setembro de 2017, para instituir a Vigilância Sentinela da Síndrome do Corrimento Uretral Masculino (VSCUM) [Internet]. Diário Oficial da União, Brasília (DF), 2020 jun 18 [cited 2020 sep 10];Seção I:61. Available from: http:// bvsms.saude.gov.br/bvs/saudelegis/gm/2020/prt1553_18_06_2020.html

21. Ministério da Saúde (BR). Secretaria de Vigilância em Saúde. Departamento de Vigilância, Prevenção e Controle das Doenças Sexualmente Transmissíveis do HIV/Aids e das Hepatites Virais. Agenda de ações estratégicas para redução da sífilis congênita no Brasil [Internet]. Brasília: Ministério da Saúde; 2017 [cited 2020 sep 10]. 34 p. Available from: http://www.aids.gov.br/system/tdf/pub/2017/65000/ agenda sifilis 10 2017.pdf?file $=1 \&$ type $=$ node $\& i d=65000 \&$ force $=1$

22. Ministério da Saúde (BR). Secretaria de Ciência, Tecnologia, Inovação e Insumos Estratégicos em Saúde. Departamento de Assistência Farmacêutica e Insumos Estratégicos. Relaçãonacional de medicamentos essenciais: RENAME 2017 [Internet]. Brasília: Ministério da Saúde; 2017 [cited 2020 set 10]. 210 p. Available from: https://bvsms.saude.gov. br/bvs/publicacoes/relacao nacional medicamentos rename 2017.pdf

23. Taylor MM, Kara EO, Alix M, Araujo L, Silveira MF, Miranda AE, et al. Phase II trial evaluating the clinical efficacy of cefixime for treatment of active syphilis in non-pregnant women in Brazil (CeBra). BMC Infect Dis [Internet]. 2020 [cited 2020 Sep 10];20:405. Available from: https:// bmcinfectdis.biomedcentral.com/articles/10.1186/s12879-020-04980-1

24. Wendland EM, Caierão J, Domingues C, Maranhão AGK, Souza FMA, Hammes LS, et al. POP-Brazil study protocol: a nationwide cross-sectional evaluation of the prevalence and genotype distribution of human papillomavirus (HPV) in Brazil. BMJ Open [Internet]. 2018 [cited 2020 Sep 10];8(6). Available from: https://doi.org/10.1136/ bmjopen-2017-021170

25. Wi T, Lahra MM, Ndowa F, Bala M, Dillon JR, Ramon-pardo P, et al. Antimicrobial resistance in Neisseria gonorrhoeae: global surveillance and a call for international collaborative action. PLoS One [Internet]. 2017 Jul [cited 2020 Sep 10];14(7):e1002344. Available from: https://doi. org/10.1371/journal.pmed.1002344

26. Unemo M, Lahra MM, Cole M, Galarza P, Ndowa F, Martin I, et al. World Health Organization Global Gonococcal Antimicrobial 
Surveillance Program (WHO GASP): review of new data and evidence to inform international collaborative actions and research efforts. Sex Health [Internet]. 2019 Sep [cited 2020 Sep 10];16(5):412-25. Available from: https://doi.org/10.1071/sh19023

27. Peeling RW, Mabey D, Kamb ML, Chen X-S, Radolf JD, Benzaken AS. Syphilis. Nat Rev Dis Prim [Internet]. 2017 Oct [cited 2018 May 8];3:17073. Available from: https://doi.org/10.1038/nrdp.2017.73

28. Domingues CMAS, Fantinato FFST, Duarte E, Garcia LP. Vacina Brasil e estratégias de formação e desenvolvimento em imunizações. Epidemiol
Serv Saúde [Internet]. 2019 oct [cited 2020 aug 10];28(2):e20190223. Available from: https://doi.org/10.5123/s1679-49742019000200024

29. Succi RCM. Recusa vacinal - que é preciso saber. J Pediatr (Rio de Janeiro) [Internet]. 2018 nov-dec [cited 2020 sep 10];94(6):574-81. https://dx.doi.org/10.1016/j.jped.2018.01.008

30. Oliveira CM, Fregnani JHTG, Villa LL. HPV vaccine: updates and highlights. Acta Cytol [Internet]. 2019 [cited 2020 Sep 10];63(2):159-68. Available from: https://doi.org/10.1159/000497617 